\title{
Sediment Accretion of a Tropical Estuarine Mangrove: Kemaman, Terengganu, Malaysia
}

\author{
Shahbudin SAAD Department of Ocean Civil Engineering, Kagoshima University, Korimoto, Kagoshima \\ 890-0065 , Japan \\ Mohd. Lokman HUSAIN Faculty of Science and Technology, University Putra Malaysia Terengganu, \\ 21030 Kuala Terengganu, Malaysia \\ Toshiyuki ASANO Department of Ocean Civil Engineering, Kagoshima University, Korimoto, Kagoshima \\ 890-0065, Japan
}

\begin{abstract}
This paper reports on a study of accretion rate and sedimentological variability in an estuarine mangrove. 116 stations were monitored for 2 years started from September 1993 to August 1995. Results show that the accretion rate for the first year was $1.46 \pm 0.13 \mathrm{~cm} / \mathrm{yr}$ and $0.66 \pm 0.04 \mathrm{~cm} / \mathrm{yr}$ for the second year thus making the average accretion for the 2 years period to be $1.06 \mathrm{~cm} / \mathrm{year}$. The average accretion rate for the monsoon season $(0.26 \pm 0.04 \mathrm{~cm} / \mathrm{month})$ was found to be significantly higher than the non-monsoon season $(0.12 \pm 0.03 \mathrm{~cm} /$ month $)$.
\end{abstract}

Key words: Vertical Accretion, deposition, seasonal changes, suspended sediment, tides

Mangroves as located in the inter-tidal area, are not very stable and may be altered easily by sea level rise. Several studies showed that the rise in sea level affect estuaries and inter-tidal areas (Jones, 1994; Ellison and Stoddart, 1992). It will cause an estuary to become wider and deeper, and it may extend the tidal penetration further upstream and alter the tidal range (Bird, 1993). Consequently, sedimentation patterns will also change. However, the mangrove community is one of the inter-tidal systems with the ability to counteract the effects of sea level rise through its lateral and vertical growth via sediment accretion.

The opportunity for sediment to settle or be deposited is greatly influenced by the frequency and duration of flooding (Cahoon \& Reed, 1995). Furukawa and Wolanski (1996) pointed out that mangrove forests function as have a "pump" of fine sediment from coastal waters to the mangrove areas. The mechanism of the pump is as follows; the mangrove roots will generate high turbulence at the time that the water enters into the forests at flood tide, which keeping the fine cohesive sediments in suspension. Sedimentation occurs during the period of near slack high tide when the turbulence vanishes and sediments will deposit on the bottom.

Deposition in mangrove areas directly determines their ability to maintain an equilibrium position in the coastal landscape. Thus this study attempts to gather physical data and information, especially on sediment accretion. Vertical sediment accretion is referred to the vertical thickness of sediment gained in certain area for a certain period. The process of sedimentation on mangroves can either be positive, denoting accretion and growth, or negative, denoting erosion. 


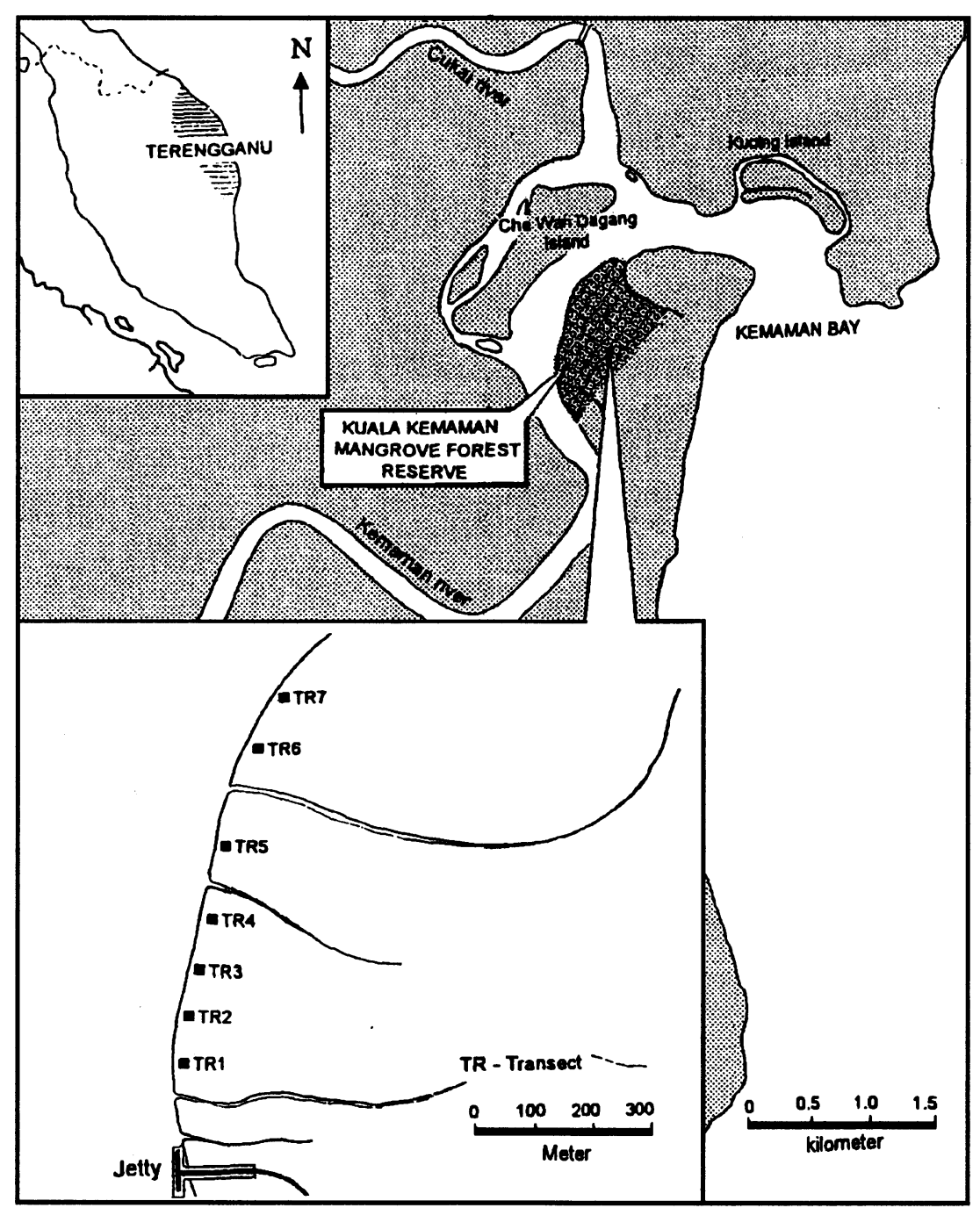

Fig. 1. Location of the study area.

\section{DESCRIPTION OF THE STUDY AREA}

The study area is situated in the district of Kemaman (Lat. $4^{\circ} 14^{\prime} \mathrm{N}$, Long. $103^{\circ} 25^{\prime} \mathrm{E}$ ), approximately $170 \mathrm{~km}$ south of Kuala Terengganu. The mangroves occupy an area about 80.9 ha and has been gazetted as a mangrove forest reserve by the Terengganu Forestry Department (Fig. 1). This forest is relatively undisturbed.

A height profile from the back mangroves to the front mangroves relative to benchmark was measured using a survey meter and rod. Fig. 2 shows the profile of all transects at the study area. The study area has gentle slopes ranging between 0.002 to 0.016 . The slopes at the front mangrove are 


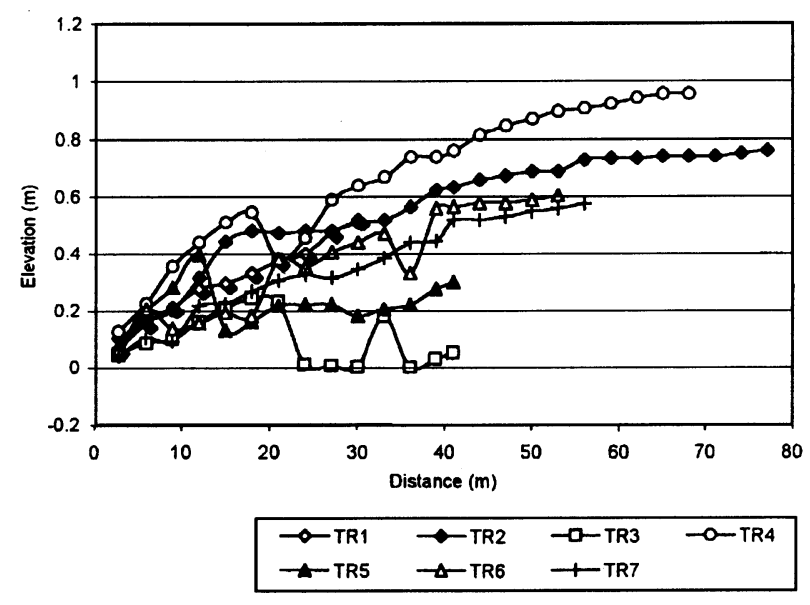

Fig. 2. Profile of ground eelevation for al the transects in the sstudy area.

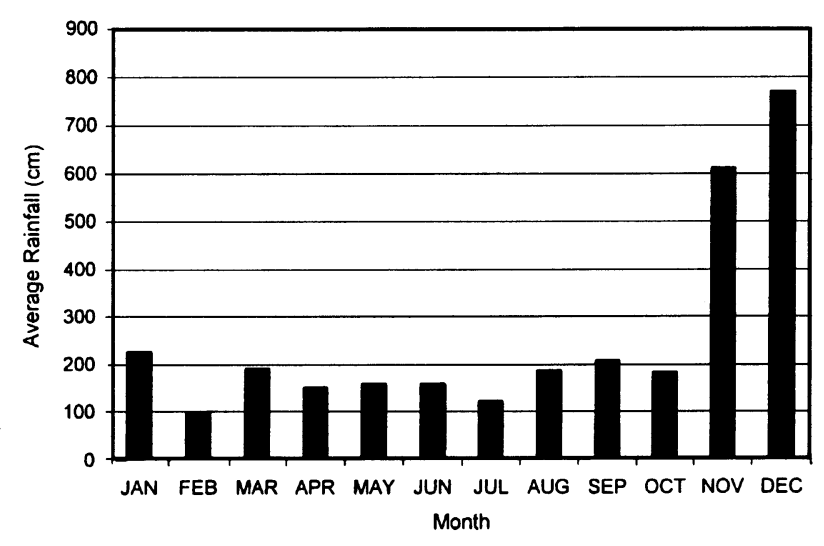

Fig. 3. Average of monthly mean rainfall at Kemaman (1981-1994).

Data source: Malaysian Meteorological Service. steep. Meanwhile the slope towards the back mangrove area is small ranging from 0.002 to 0.008 .

The mangrove area is approximately $250 \mathrm{~m}$ upstream from the river mouth and lies on the southern bank of the Kemaman estuary. The tide is semi-diurnal, with a mean range of $1.8 \mathrm{~m}$ and floods the areas twice daily (Hydrographic Department of the Royal Malaysian Navy, 1995). However, total inundation of the mangrove area occurs only during spring tides, when water rises to approximately $2.6 \mathrm{~m}$ (tidal datum).

The Kemaman River has a freshwater discharge of about $80 \mathrm{~m}^{3} \mathrm{~s}^{-1}$ during the non- monsoon seasons and $500 \mathrm{~m}^{3} \mathrm{~s}^{-1}$ during the monsoon seasons. The monsoon season normally begins from the month of November and ends in January. The mean annual rainfall, as observed at Kemaman during 1981 to 1994 is $3064 \mathrm{~mm}$. Fig. 3 shows a monthly variation of rainfall distribution for Kemaman area. During high rainfall the area receives minimum sunshine hours and evaporation. High sunshine hours and evaporation occurred during April, May and June which corresponds to the low rainfall duration during the non-monsoon period (Fig. 4).

According to the twenty years (1968 to 1987) accumulated data obtained from the Malaysian 


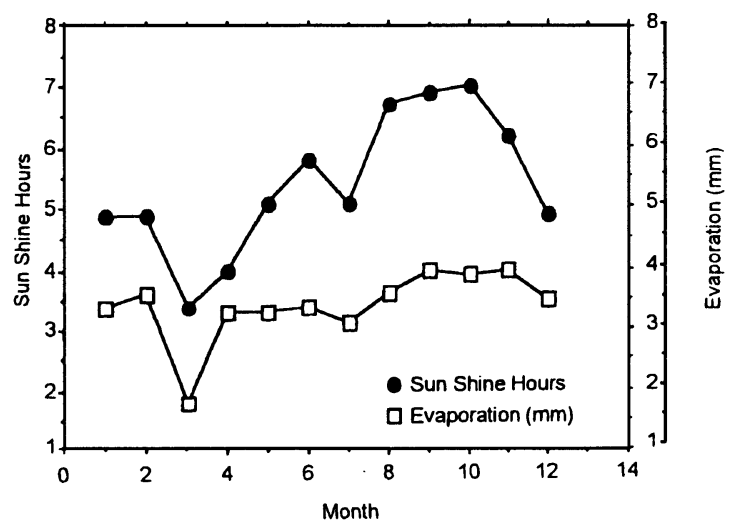

Fig. 4. Relationship between sunshine hours and evaporation in Kemaman, Terengganu.

Meteorological Service, strong winds with a long frequency periods occurred from November to January and from May to July. Fifty percent of the wind is from the northeasterly and southwesterly direction. The northeasterly wind coincides with the incoming wind normal to the coast of Kemaman bay. The maximum velocities for the northeasterly winds are relatively higher than southeasterly winds with a mean velocity $5.5-7.8 \mathrm{~m} / \mathrm{sec}$ and $3.4-5.4 \mathrm{~m} / \mathrm{sec}$ respectively.

\section{MATERIALS AND METHODS}

Determination of Sediment Accretion The methodology applied in this work is based on measuring the thickness of a vertical sediment section divided by the time span necessary for its deposition. The study spanned two years. The first year was from September 1993 to August 1994 while the second year was from September 1994 to August 1995.

For the purpose of this study 116 sampling points were set up inside the mangroves area. At each sampling point a slab of perspex $(9 \mathrm{~cm} \times 9 \mathrm{~cm} \times 1.5 \mathrm{~mm})$ was placed at a recorded depth to act as a marker level. As a stabilization measure, the disturbed sediment above the markers were left for one month before initial readings of marker level depths were recorded. As another measure to aid in the stabilization of sediments above the marker levels, five holes, measuring approximately $3-4 \mathrm{~mm}$ in diameter, were drilled in each perspex slab to enable water to pass through from the surface to the bottom. After the perspex markers were installed, the thickness of sediments above the markers were then measured on a monthly basis. The thickness of sediment at every sampling point was determined by taking the average of six readings per marker. Accuracy of reading is approximately $\pm 2 \mathrm{~mm}$. The average thickness of the sediment for the month in study is then subtracted by the thickness of sediment obtained from the previous month. A positive value indicates accretion while a negative value indicates erosion.

\section{RESULTS AND DISCUSSION}

\section{Accretion Rates}

Table 1 shows the summary of average accretion rates for the duration of the study period. Three 
Table 1. Average monthly accretion data of each month for the two years.

\begin{tabular}{lrr}
\hline Month & 1993-1994 & 1994-1995 \\
\hline September & 0.08 & 0.01 \\
October & 0.18 & 0.01 \\
November & 0.59 & 0.14 \\
December & 0.25 & 0.16 \\
January & 0.39 & -0.01 \\
February & 0.95 & -0.02 \\
March & & -0.17 \\
April & 0.56 & -0.13 \\
May & -0.20 & 0.11 \\
June & 0.45 & 0.21 \\
July & 0.11 & 0.03 \\
August & 0.00 & 0.30 \\
Average & 0.13 & 0.06 \\
\hline Standard deviation & 0.43 & 0.14 \\
\hline
\end{tabular}

Table 2. Accretion rates on other inter-tidal systems.

\begin{tabular}{|c|c|c|c|}
\hline Study & Method & $\begin{array}{l}\text { Accrealion Rat } \\
(\mathrm{cm} / \mathrm{yr})\end{array}$ & Location \\
\hline $\begin{array}{l}\text { Chapman \& } \\
\text { Ronaldson (1958) }\end{array}$ & Brick-dust marker & 0.1 & $\begin{array}{l}\text { New Zealand Salt } \\
\text { Marsh }\end{array}$ \\
\hline Bird (1971) & Stake & 0.8 & $\begin{array}{l}\text { Avicennia forest } \\
\text { Southern Australia }\end{array}$ \\
\hline $\begin{array}{l}\text { Harrison \& Bloom } \\
\text { (1977) }\end{array}$ & $\begin{array}{l}\text { Artificial marker } \\
\text { Horizon }\end{array}$ & $0.2-0.5$ & $\begin{array}{l}\text { Connecticut } \\
\text { S. patens marsh }\end{array}$ \\
\hline $\begin{array}{l}\text { Armentano \& } \\
\text { Woodwell (1975) }\end{array}$ & ${ }^{210} \mathrm{~Pb}$ & $0.47-0.63$ & $\begin{array}{l}\text { Long Island, NY } \\
\text { Flax pond, S. alterniflora }\end{array}$ \\
\hline $\begin{array}{l}\text { Spenceley } \\
(1977,1982)\end{array}$ & Grids of Stakes & 046 & $\begin{array}{l}\text { Avicennia North } \\
\text { Earth Australia }\end{array}$ \\
\hline $\begin{array}{l}\text { DeLaune et al. } \\
\text { (1978) }\end{array}$ & ${ }^{137} \mathrm{Cs}$ & $\begin{array}{l}1.35 \\
075\end{array}$ & $\begin{array}{l}\text { Barataria Basin } \\
\text { LA }\end{array}$ \\
\hline Stevenson et al. (1985) & ${ }^{210} \mathrm{~Pb}$ & $017-0.36$ & Chesapeake Bay \\
\hline $\begin{array}{l}\text { Onema \& DeLaune } \\
\text { (1988) }\end{array}$ & ${ }^{137} \mathrm{Cs}$ & $\begin{array}{l}1.0 \\
1.5\end{array}$ & $\begin{array}{l}\text { Rattekaai, salt marsh } \\
\text { St. Annaland, salt marsh }\end{array}$ \\
\hline Lynch et al (1989) & $\begin{array}{l}{ }^{210} \mathrm{~Pb} \text { and }{ }^{137} \mathrm{Cs} \\
\text { isotopes }\end{array}$ & 0.3 & Mexico, mangrove \\
\hline Woodroffe (1990) & Radiocarbon & 0.6 & Northern Australia mangrove \\
\hline $\begin{array}{l}\text { French \& Spencer } \\
\text { (1993) }\end{array}$ & $\begin{array}{l}\text { Artificial marker } \\
\text { Honzon }\end{array}$ & 0.56 & Norfolk, U.K \\
\hline Leonard et al. (1995) & Sediment traps & $0.12-0.76$ & $\begin{array}{l}\text { West-central FL } \\
\text { J. roemrianus (Cedar Creek) }\end{array}$ \\
\hline This study & $\begin{array}{l}\text { Artificial marker } \\
\text { horizon }\end{array}$ & $0.64-1.46$ & $\begin{array}{l}\text { East coast of Peninsular } \\
\text { Malaysia, mangrove }\end{array}$ \\
\hline
\end{tabular}

values can be cited to represent the average accretion rate (AAR) for this study: $1.46 \pm 0.13 \mathrm{~cm} / \mathrm{yr}$ for this fist year of study; $0.66 \pm 0.04 \mathrm{~cm} / \mathrm{yr}$ for the second year and $1.06 \mathrm{~cm} / \mathrm{yr}$ as the average of the two years. They are nevertheless comparable to accretion rates reported at other intertidal areas where data are available, no such data being apparently available elsewhere in Malaysia (Table 2). The higher value of AAR, $1.46 \mathrm{~cm} / \mathrm{yr}$ is slightly less than AAR of $1.5 \mathrm{~cm} / \mathrm{yr}$ at St. Annaland marsh (Oenema and Delaune, 1988). The lower value of $0.66 \mathrm{~cm} / \mathrm{yr}$ is comparable to the AAR of $0.75 \mathrm{~cm} / \mathrm{yr}$ at Barataria Basin Louisiana (Delaune et al., 
Fig. 5. Monthly accretion rate during 1994-1995.

Fig. 6. Relation between accretion and distance from mangrove edge.
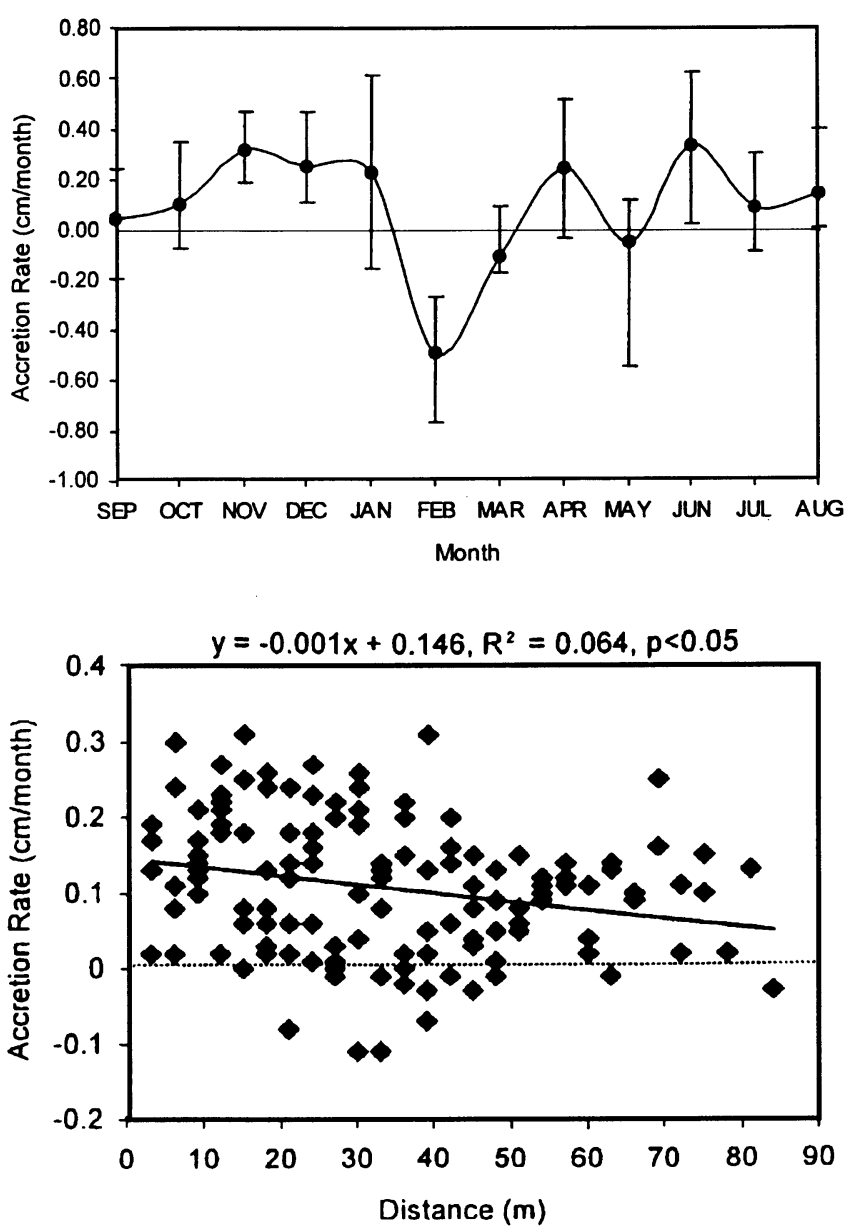

1978 ) and $0.76 \mathrm{~cm} / \mathrm{yr}$ at West Central Florida (Leonard et al., 1995).

Two factors can be considered to explain the high rate of accretion. The first is that this mangrove is still in the process of attaining maturity. Immature mangroves colonize lower land, flooded more often by tides, thus accounting for more sediment accretion. Secondly the location inside the estuary, close to the mouth, provides it with two sediment sources; fluvial and tidal.

\section{Monthly Accretion}

There was no data on March 1994 because sampling could not be conducted as a consequence of large tidal flooding and strong currents occurring inside the mangroves. Fig. 5 shows the average monthly accretion rates. There is a positive accretion rates for all months except February and March. The highest average accretion rates over the two years of study are found in the period from November to January corresponding to the monsoon season (Fig. 3).

\section{Variability of Sediment Accretion by Distance}

As seen from Fig. 6, there is a negative relationship between the accretion and distance from the 

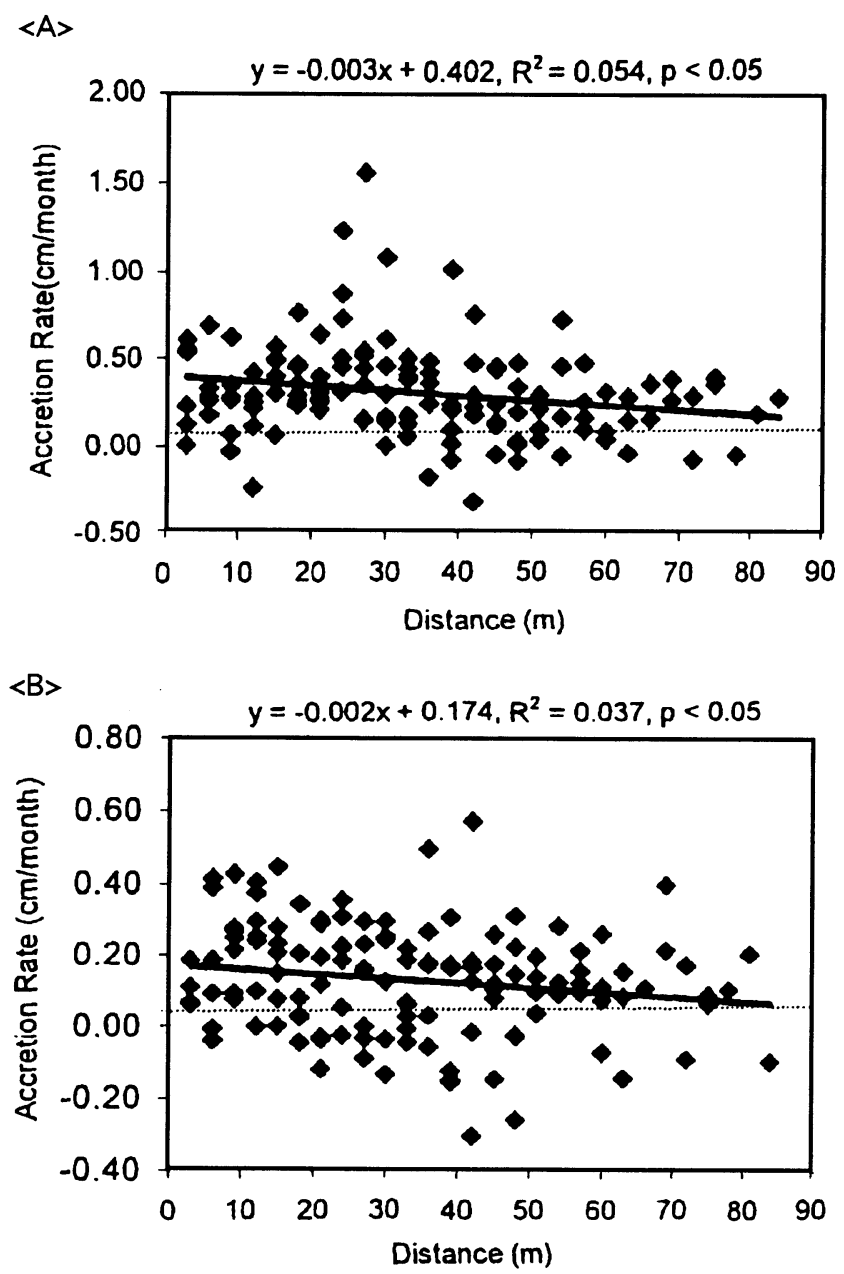

Fig. 7. Relationship between accretion and distance from mangrove edge for monsoon $\angle A>$ and non-monsoon season $<B>$.

mangrove edge. Accretion rates tend to decrease towards the back mangrove. The higher accretion at the front mangrove, frequently referred to as the full high tide zone, may result because this zone is exposed more frequently to tidal inundation. Sediment at the front mangrove seemed to remain in the slurry form for a longer period compared to the back mangrove. This statement is supported by Reed (1989), who postulated that the process of sediment deposition and sedimentation preferentially occur in the slushy zone. In addition, the front mangrove is situated comparatively lower than the sea level and is also located near to the sources of sediment from both the estuary and river. As a result, the accretion of sediment is more concentrated at the front mangrove compared to the back mangrove.

\section{Seasonal Changes and Sediment Accretion}

Kuala Kemaman mangroves, like most other coastal environments, are subjected to natural periodicity in the intensity of physical processes. A dominant seasonal forcing is the annual monsoon season, starting in November and ending in January, bringing with it heavy rainfall. At that time the river 
discharge and the riverine sediment load are significantly higher. According to the Drainage and Irrigation Department of Malaysia, the suspended sediment concentration of the Kemaman river during this season range from 50 to $100 \mathrm{ppm}$ while during the non-monsoon season it ranges only from 8 to 20 ppm only.

Accordingly, the rates of accretion between the monsoon $(\mathrm{M})$ and non-monsoon $(\mathrm{NM})$ were found to differ significantly during the $M$ season $0.26 \pm 0.04 \mathrm{~cm} /$ month compared to $0.12 \pm 0.03 \mathrm{~cm} / \mathrm{month}$ in the NM season. Although, the accretion rate was higher during the $M$ season, the spatial distribution of accretion rates was similar to that of the NM season: it decreased with distance inside the mangrove. The relation was statistically significant for both $\mathrm{M}$ and NM seasons (Fig. 7).

\section{CONCLUSION}

The estuarine mangrove at Kuala Kemaman is typical of any inter-tidal ecosystem in the sense that it acts as a sediment trap. The average accretion rate was $1.46 \mathrm{~cm} / \mathrm{yr}$ which is about ten to fifteen times greater than the predicted future sea level rise of 0.1 to $0.5 \mathrm{~cm} / \mathrm{yr}$. This finding suggests that mangrove forests may mitigate the impact of sea level rise. The high average accretion rates at the front, middle and back mangrove also indicate that this mangrove may still be prograding and in an immature stage.

The monsoon months play a major role in the supply of sediment to the mangrove. The accretion rates during the monsoon months are significantly higher than those during the non- monsoon months.

ACKNOWLEDGEMENTS This research was conducted with joint funding from the Malaysian Ministry of Science under the Intensified Research for Priority Areas (IRPA) project number 01-0204-262 and Grant -in aid- for International Scientific Research of the Ministry of Education, Science, Sports and culture of Japan (no. 08041111). The authors wish to express their gratitude to Prof. Toyohiko Miyagi and his mangrove team, Kartini Mohamed, Mohd. Zan, Ku Kassim Ku Yaacob and Razali for their invaluable assistance and hospitality throughout the sampling period.

\section{REFERENCES}

Armentano, T. V. \& Woodwell, G. M. 1975. Sedimentation rate in a Long Island marsh determined by ${ }^{210} \mathrm{~Pb}$ dating. Limnology and Oceanography 20: 452-456.

Bird, E. C. F. 1971. Mangroves as land-builders. Victorian Naturalist 88: 189-197.

, 1993. Sea level rise impacts in Southeast Asia: An overview. Malaysian Journal of Tropical Geography 24 (1/2): 107-110.

Cahoon, D. R. \& Reed, D. J. 1995. Relationship among marsh surface topography, hydroperiod, and soil accretion in a deteriorating Louisiana Salt Marsh. Journal of Coastal Research 11(2):357-369.

Chapman, V. J. \& Ronaldson, J. W. 1958. The mangrove and salt mash flats of the Auckland Isthmus, New Zealand. Department of Scientific and Industrial Research, Bulletin 125: 79.

DeLaune, R. D., Patrick, W. H. \& Buresh, R. J. 1978. Sedimentation rates determined by ${ }^{137}$ Cs dating in a rapidly accreting salt marsh. Nature 275 : $532-533$.

Ellison, J. C. \& Stoddart, D. R. 1992. Mangrove ecosystem collapes with predicted sea level rise: Holocene analogues and implications. Journal of Coastal Research 7: 151-165. 
French, J. R. \& Spencer,T. 1993. Dynamics of sedimentation in a tide dominated backbarrier salt marsh, Norfolk, UK. Marine Geology 110: 315:331.

Furukawa, K. \& Wolanski, E. 1996. Sedimentation in mangrove forest. Mangrove and Salt Marshes 1 (1): 3-10.

Harrison, E. Z. \& Bloom, A. L. 1977. Sedimentation rates on tidal salt marshes in Connecticut. Journal of Sedimentary Petrology 47: 1484-1490.

Jones, G. 1994. Global warming, sea level change and the impact on estuaries. Maritime 2; 42-48.

Leonard, A. L. Hine, C. A. \& Luther, E. M. 1995. Surficial sedimentation transport and deposition processes in a Juncus roemerianus Marsh, West Central Florida. Journal of Coastal Research 11: 322-336.

Lynch, J. C., Meriwether, J. R., McKee, B. A., Vera-Herrera, F. \& Twilley, R. R. 1989. Recent accretion in mangrove ecosystem based on ${ }^{137} \mathrm{Cs}$ and ${ }^{210} \mathrm{~Pb}$. Estuaries 12: 264-299.

Oenema, O. \& DeLaune, R. D. 1988. Accretion rates in salt marshes in the Eastern Scheldt, SouthWest Netherlands. Estuarine, Coastal and Shelf Science 26: 379-394.

Reed, D. J. 1989. Patterns of sediment deposition in subsiding coastal salt marshes, Terrebone Bay. Lousiana: The Role of Winter Storm. Estuaries 12(4): 222-227.

Spenceley, A. P. 1977. The role of pneumatophores in sedimentary processes. Marine Geology 24: 3137.

$\longrightarrow$ 1982. Sedimentation patterns in a mangal on magnetic Island near Townsville, North Quensland, Australia. Singapore Journal of Tropical Geography 3 : 219-230.

Stevenson, J. C., Kearney, M. S. \& Pendleton, E. C. 1985. Sedimentation and erosion in a Chesapeake Bay brakish marsh system. Marine Geology 67: 213-235.

Woodroffe, C. D. 1990. The impact of sea level rise on mangrove shorelines. Progress in Physical Geography 14: 483-520. 
Shahbudin SAAD, Mohd. LOKMAN HUSAIN, 浅野敏之 マレーシア・トレンガヌ 州 Kemaman エスチュアリーのマングローブ群落における底泥の堆積特性

地球温暖化による海面上昇がマングローブ生態系にいかなる影響を及ぼすかは, 検討すべき重要な課題で ある。マングローブ水域の物理過程は, 生物・化学過程を包含した環境形成の基盤と捉えられる。マング ローブの錯綜した地上根は，流れを弱め底泥を堆積させる機能を持つ。将来の海面上昇の定量的な影響評 価を行う上では, マングローブ群落内の底質堆積速度と海面上昇の相対関係を理解しておく必要があろう。 本研究は, 2 年間にわたって現地調查されたマレーシア半島東岸のマングローブ湿地帯で底泥地盤の堆積 高の測定結果を報告したものである。

現地調查は, Kuala Terengganu 市の $170 \mathrm{~km}$ 南方に位置する Kemaman 地区の 81 ha のマングローブ 湿地帯において 1993 年 9 月から 1995 年 8 月までの 2 力年にわたって行われた。毎月一回低潮時に 116 ヶ 所のポイントで地盤高の測定と底質のサンプリングを行った。観測期間内の現地の月別降水量, 日照時間, 潮位, 風速など背景となる気象データも取得した。

本研究から次のような底泥の堆積特性が明らかになった。領域全体の平均堆積速度として 1.46 $\mathrm{cm} /$ year が得られた。この值は将来予測される海面上昇速度の $10 \sim 15$ 倍で, このマングローブ湿地帯が 海面上昇のインパクトに十分対応できることがわかった。底泥の堆積速度はモンスーン季で大きく, 非モ ンスーン季では顕著に隇少した。エスチュアリーに面したマングローブ前面部とそれより陸側の後背部を 比べると, 冠水時間の長短・流れの静穞度の違いにより, 堆積量はマングローブエッジからの距離ととも に減少し, 平均粒径は細かくなることがわかった。マングローブ前面では若いマングローブ樹木が慗茂し, そこで底質堆積量が大きいことは，繁茂域がエスチュアリ一側に前進していくことを意味している。すな わち，土地造成能力を持った生物形成海岸の性格を有することが示された。 